\title{
The Social Economy as a Factor of Economic Development and Resilience of Population in Rural Areas. A Study of Mediating Effects in Castilla-La Mancha (Spain)
}

\author{
Marcos Carchano ${ }^{1, *(\mathbb{D})}$, Inmaculada Carrasco ${ }^{1,2} \mathbb{D}$, Sebastián Castillo ${ }^{2}$ and M. Carmen García-Cortijo ${ }^{2}$ (D) \\ 1 Faculty of Economics, University of Castilla-La Mancha, 02071 Albacete, Spain; \\ Inmaculada.Carrasco@uclm.es \\ 2 Institute of Regional Development, University of Castilla-La Mancha, 02071 Albacete, Spain; \\ Sebastian.Castillo@uclm.es (S.C.); MariaCarmen.GCortijo@uclm.es (M.C.G.-C.) \\ * Correspondence: Marcos.Carchano@alu.uclm.es
}

Citation: Carchano, M.; Carrasco, I.; Castillo, S.; García-Cortijo, M.C. The Social Economy as a Factor of Economic Development and Resilience of Population in Rural Areas. A Study of Mediating Effects in Castilla-La Mancha (Spain). Sustainability 2021, 13, 5544 https://doi.org/10.3390/su13105544

\section{Academic Editors: Juan}

Carlos Rodríguez Cohard and

Antonio Vázquez Barquero

Received: 30 April 2021

Accepted: 13 May 2021

Published: 16 May 2021

Publisher's Note: MDPI stays neutral with regard to jurisdictional claims in published maps and institutional affiliations.

Copyright: (c) 2021 by the authors. Licensee MDPI, Basel, Switzerland. This article is an open access article distributed under the terms and conditions of the Creative Commons Attribution (CC BY) license (https:// creativecommons.org/licenses/by/ $4.0 /)$.

\begin{abstract}
Depopulation is a serious problem facing developed countries, among them Spain. It is especially severe in rural areas, where some vicious circles emerge, nourished by reduced infrastructures and services, deteriorated quality of life, the low inflow of new inhabitants, low local development and an aged population. In this context, social economy institutions may be a key factor in the fight against population decline, having a leading role in reactivating economic dynamism through the creation of stable, high-quality jobs, promoting the local endogenous development of rural areas, helping enhance income in those spaces, encouraging the arrival of people and impacting positively on social cohesion, and enabling sustainable growth. This paper focuses on Castilla-La Mancha, an eminently rural region, which is among the areas most severely impacted by the loss of population in Spain. The aim is to analyze the factors that affect the settlement of population, and to demonstrate that social economy institutions may be a resilience factor of rural population. A partial least squares model, composed of 8 constructs related to 21 variables extracted from data for 2017 and 2018 on the 613 municipalities, allows us to demonstrate that the existence of social economy entities helps to anchor population and increase the resilience of this territory.
\end{abstract}

Keywords: population resilience; social economy; local development

\section{Introduction}

Depopulation is a complex demographic and territorial phenomenon, referring to a chronic decrease in inhabitants and affecting the spatial distribution of population. It is currently one of the most serious problems facing many countries, including Germany, Poland, Italy, Russia, Japan, the United States, Italy, Greece, and Spain [1-8]. In the case of Spain, such is the significance of population decline that $85.5 \%$ of the people consider it a serious or very serious problem [9] and the public authorities have set up a number of commissions to address the problem of depopulation (the Senate Select Committee on Demographic Development and the Government Commission on the Demographic Challenge, besides the creation of commissions and working groups by various political parties). The situation at a European level is similar, where demographic change is a major challenge, especially in rural areas. The 2020 strategy addressed these demographic challenges from the perspective of employment, education, innovation, poverty reduction, climate, and energy. The implementation of rural development policies for the 2014-2020 period, established under the framework of the Common Agricultural Policy (CAP), has attempted to alleviate this problem. Furthermore, the European Commission has pledged to actively include depopulation among the objectives for the following planning periods, with the intention of the most badly affected regions benefitting from specific development programs. The new recovery, transformation and resilience plan, designed by the Spanish 
government after the COVID-19 crisis, addresses the demographic challenge to ensure territorial cohesion in one of the four priority axes identified, in order to ensure that the plan's effects reach the entire territory, both to large urban and more dynamic areas, such as small rural municipalities or areas affected by the demographic decline.

The dynamic of population is heterogeneous and relates to urbanization tendencies [10]. Depopulation affects small municipalities more severely, and it is an eminently rural phenomenon [11,12]. In Spain, 3926 municipalities have a population density of less than $12.5 \mathrm{hab} / \mathrm{km}^{2}$ (the demographic risk threshold defined by the EU) and occupy $48 \%$ of the country's area [11]. Since 1997, municipalities of fewer than 1000 inhabitants have lost more than $15 \%$ of their population, while those between 1000 and 5000 have lost less than $5 \%$ and bigger rural municipalities (more than 5000 inhabitants) have increased their population by more than $6 \%$ [10].

One of the regions most affected by decline and low population density is CastillaLa Mancha. During the last decade, its number of inhabitants has reduced by more than 100,000 people, positioning itself among those Spanish communities with fewer inhabitants $(2,032,863)$. The loss of population in this region consists of multiple interrelated dimensions. On the one hand, it has an aged population structure, where people aged 65 and over account for $19 \%$ of the total, while the population under the age of 16 represents $16 \%$. This situation is aggravated in the rural environment (municipalities with fewer than 2000 inhabitants), where the percentage of people over 65 years old reached $29 \%$ in 2019. It is also impacted by the negative natural increase of population and the consequent progressive emptying of the population in the rural environment. On the other hand, attention must be paid to geographical dispersion and the low population densities of Castilla-La Mancha, which presents the lowest population density of the nation, with a rate of 26 inhabitants per square kilometer, a situation that is aggravated if we take into account that there are areas, such as most of the provinces of Cuenca and Guadalajara, where it does not exceed 5 inhabitants per square kilometer. Specifically, $67.4 \%$ of municipalities ( 619 out of 919) have a population density below $12.5 \mathrm{hab} / \mathrm{km}^{2}$, and more than $90 \%$ of the region is classified as a rural environment, that is, $70 \%$ of the 919 municipalities have a population of fewer than 1000 inhabitants, 24\% have between 1001 and 5000 inhabitants, while the rest (6\%) have more than 5000 inhabitants. According to the latest report prepared by the regional government as part of its depopulation strategy, approximately $30 \%$ of municipalities are sparsely populated or at risk of depopulation, of which $2.6 \%(53,760)$ of the population are at imminent risk of disappearance. Of the 679 municipalities that lose population, $562(83 \%)$ have fewer than 1000 inhabitants, which highlights the close relationship between the size of the municipalities and the intensity of the demographic problems, which are concentrated in the smallest ones. This situation not only reflects the eminently rural character of this region, but also highlights the demographic phenomenon of depopulation and low population intensity, which particularly affects the provinces of Cuenca and Guadalajara, as well as certain counties or rural areas of the west and south of the provinces of Toledo, Ciudad Real and Albacete.

Depopulation comes about as a result of very diverse factors, such as those related to the natural environment, infrastructures, the territorial, political and administrative organization, the economic model and social dynamics. It behooves us, therefore, to look for causes and solutions. Local development theory provides us with an adequate framework for this analysis. Local development strategies, which aim to increase economic, political, and social wellbeing through endogenous changes, take on a leading role in placing the territory at the center of their policy, acting as the main development actor through the interaction of economic factors [13,14], in accordance with existing local conditions (productive structure), labor market, entrepreneurship and innovation capacity, available capital, regulations and institutions, etc. [15]. In this context, social economy companies must be taken into account during the implementation of such endogenous development policies [16-18] since their partners and activity are linked to the territory, enhancing the development of the rural landscape [19-21] and integrating the needs and specifications of 
the environment [22]. In short, the fight against demographic decline in Castilla-La Mancha requires comprehensive measures based on the principles of local development policy, where the greatest success of the interventions depends on the degree of involvement of the local actors [23].

Previous studies establish a theoretical framework for demonstrating that social economy companies are involved in the process of local development and consequently in population fixation [21,24-34]. The main contribution of this work is to present an empirical process analysis model that demonstrates both the direction of the relationships between this type of company and population fixation, as well as their intensity. Thus, the objective of this study is to analyze the factors that influence the fixation of the population in a certain territory, and to demonstrate that the existence of social economy entities can be a factor of resilience for the population in rural territories. The study is organized into four parts. Following this introduction, the second section reviews the literature, which will provide the background to the theoretical model. The third section presents the methodology and the data used in the model, which is a partial least squares model, composed of 8 constructs related to 21 variables extracted from data for 2017-2018 on the 613 municipalities in Albacete, Cuenca, and Guadalajara, three provinces in the region of Castilla-La Mancha (Spain). The fourth section presents our results and discussion, and finally our conclusions.

\section{Determinants of the Settlement of Population in a Particular Territory: The Theoretical Model}

Of the main factors involved in the process of loss of population in the rural environments, we can highlight the following [35-41]: 1. shortfall in the provision of basic services such as educational, health or leisure services; 2 . aging and masculinization of the population; 3. lack of basic infrastructures, such as communication infrastructures, which limits mobility and accessibility to certain basic services; 4 . a non-dynamic labor market (predominantly agricultural) with a lack of job opportunities, especially for young people and women. Fueled by the above, migratory movements also becomes one of the most important causes of depopulation [35,42,43].

In this context, without abandoning the main goal of this work, six hypotheses ( $\mathrm{H} 1$, $\mathrm{H} 2, \mathrm{H} 3, \mathrm{H} 4, \mathrm{H} 5$ and H6) are introduced in a confirmatory way. They relate to the influence of demographic factors and access to basic services on the size of the population, and enrich the empirical model proposed to contrast the main hypothesis ( $\mathrm{H} 7$ and $\mathrm{H} 8$ ).

\subsection{Impact of Demographic Factors on Population Settlement in a Specific Territory}

From a demographic perspective, population loss is caused by two main factors: the negative natural population change $[44,45]$ and the negative migration balance [43]. The first, understood as the population variation due to the difference between live births and deaths, is mainly motivated by both the reduction of birth rates [46], and the high aging rates of the population $[1,47]$ which, in the case of Spain, is mainly concentrated in small rural municipalities (fewer than 1000 inhabitants) in which $30 \%$ of the population exceeds 65 years, and $15 \%$ exceeds 80 [11].

Then, considering that low vegetative growth has become one of the main causes of depopulation in rural areas $[48,49]$, it raises the first hypothesis:

Hypothesis 1 (H1). The greater the natural population change in a municipality, the greater is the population level.

Demographic growth will, therefore, depend on the ability of migration movements to compensate for low birth rates. In this sense, the beginning of the 21st century has borne witness to a new growth of both internal and external migration in Spain, with Madrid, the archipelagos and the Mediterranean coastal areas attracting the greatest influx of persons [50]. Hence, we find regions with positive net migration and others, with the highest depopulation rates, where net migration is negative. This negative migratory 
balance, characterized by migration toward the larger centers of population [35], has a negative effect on population settlement in the territory in question, and the persistence of such migratory movements has a negative impact on population resilience [51]. Saco [52] proposes seven factors that fuel negative net migration: tertiarization of the economy, the level of qualifications in the population, relocation of production processes, economic globalization, urbanization and the spread of new technologies. In this sense, Godenau [53] posits that employment opportunities play a key role in determining migratory flows. In other words, migratory movements head towards areas with higher levels of job creation. Furthermore, this process is exacerbated by the uprooting of women in rural regions, which is a product of the characteristics of the labor market in these areas, the access to mobility [54] and the outflow of young people in search of those educational opportunities needed to continue their training, given the limitations in their places of origin [55]. The outflow of such people has the effect of aggravating population aging [56], impoverishment and the lack of dynamism in rural areas [57]. Breaking this vicious circle is essential to encourage the repopulation of territories.

A deeper analysis of the migration process involves looking at the key role of immigrants in the rural environment, given that they act as "shock absorbers" in the depopulation crisis [58,59], rejuvenating and revitalizing not only demographic structures but also local labor markets $[43,60,61]$, indirectly contributing to natural population change $[62,63]$.

The study by Sampedro and Camarero [64] concurs with these notions, but also underlines, however, that mid- and long-term repopulation derived from this process will also depend on the characteristics of both the recipient populated areas (facilities, labor market, etc.) and the immigrants. Foreign immigrants are typically young adults who arrive in search of work, being employed mainly in sectors such as construction, hotels, catering, agriculture, and domestic service (usually unskilled employment) [65], suggesting a direct relationship between the arrival of immigrants and an increase in the multi-functionality of rural areas [66]. The arrival of immigration is thus considered to counteract depopulation. We thus define net migration as the difference between migratory inflow and outflow, and given the above, our second and third hypotheses are:

Hypothesis 2 (H2). Positive net migration helps maintain population levels in municipalities due to its contribution to a natural increase.

Hypothesis 3 (H3). There is a positive relationship between the labor market and net migration.

\subsection{Impact of Access to Services and Basic Facilities on Population Settlement in a Territory}

Many factors determine the quality of life in rural environments, but health and education services are of undoubted significance [55]. There exists a direct association between health and education services and citizens' quality of life. This relationship is even more pronounced in rural areas, given that the lack of such services implies the need to travel to nearby centers of population, with private vehicle ownership being essential to mobility [38]. The deterioration of these services would lead to a renewed rural exodus [67-73]. The loss of attractiveness in local communities leads to the loss of social activity, and the community gradually becomes lethargic [74]. The sense of having "no future" could cultivate the vicious circle of poor development prospects [75].

Schools attract new residents and encourage migratory flows, since the better the provision and quality of educational infrastructures in rural areas, the greater is the likelihood of attracting new inhabitants [40], with rural schools playing an important role in patterns of population mobility [76]. Furthermore, school closures have a negative influence on the local demography and economy, mainly in remote regions [77,78]. Educational attainment tends to be strongly correlated with the development possibilities of regions; rural areas with lower levels of educational attainment present higher unemployment, poverty rates and population decline compared to those with higher educational levels [79]. Although the concentration of services in larger settings is not an exclusive phenomenon of rural and depopulated areas [73], it does have a greater impact. 
Along the same lines, Alburquerque [80] points out the importance of investments in education, basic infrastructures and social services in the process of territorial economic development, since the greater possibility of education and health services encourage a higher rate of economic growth [81] through the generation of economic activity and the attraction of a new population [82,83], which favors both the maintenance of social capital [84] and rural development [85]. Thus, the disappearance of certain educational services supposes the beginning of a spiral of suppression of other services [86] which deepens the risk of poverty and increases depopulation.

Then, even if the concentration of services and population maintain relationships in both directions, based on the above, we propose the following four hypotheses:

Hypothesis 4 (H4). The greater the provision of health services in a municipality, the greater the boost of population by the arrival of new immigrants.

Hypothesis 5 (H5). The greater the provision of health services in a municipality, the greater the level of economic activities.

Hypothesis 6 (H6). The greater the provision of education services in a municipality, the greater the boost of population by the arrival of new immigrants.

Hypothesis 7 (H7). The greater the provision of education services in a municipality, the greater the level of economic activities.

The changes in rural employment in the OECD countries during the past decades have underlined the rising role of occupation in services and, in some cases, industrial activities, compensating for the decline in agricultural employment. Nevertheless, this is not a homogeneous trend, and the relative success of some rural areas depends on economic dynamism. In many, but not all, rural areas, the secular decline in agricultural employment has been more than counterbalanced by growing employment in these other sectors [87]. The authors Johnson and Lichter [12] argue that in the United States there exist rural enterprise zones where population growth has been strong for decades (including in nonmetropolitan counties), because they have been able to diversify their economic fabric, complementing the agricultural one, as the population is close to employment centers.

In this context, and considering all of the above, we could question how the economic activity and the labor market relates to the population level, giving rise to the following hypotheses:

Hypothesis $\mathbf{8}$ (H8). The greater the level of economic activity, the better the labor market performance.

Hypothesis 9 (H9). The better the labor market performance, the greater the natural population growth.

Hypothesis 10 (H10). The better the labor market performance, the greater the population level.

\subsection{Social Economy Institutions, Endogenous Development, and Population Density}

Local development strategies, which emerged in the 1970s in response to the process of globalization and economic integration, aim to increase economic, political, and social wellbeing through endogenous changes driven by local resources, which are the potential for community development [13,14]. They act through the interaction of economic and productive factors [88], where the territory is positioned at the center of politics as a development actor [13]. Therefore, depopulation and a low intensity of population, as territorial phenomena, perform as restricting elements that limit the endogenous growth possibilities.

Being the territory at the core of local development strategies, it is expected that there will be differences between the development policies implemented in each region [89], as these must be formulated in accordance with existing local conditions (productive struc- 
ture, labor market, entrepreneurship and innovation capacity, available capital, regulations, and institutions, etc.) [15]. In this regard, authors such as Alburquerque [90] or VázquezBarquero [91] highlight the importance of the good organization of the local productive system, job creation, promotion of innovation systems, participation of local actors (institutions, companies, and citizens), improvement of the social level and the creation of networks of companies, among others, as necessary elements of this transformation process.

Institutions also intervene in the efficiency of local development policy $[75,92,93]$, where territorial governance networks play a decisive role in promoting endogenous development $[94,95]$ through experience and knowledge of the specific needs of the environment [5]. In this regard, Rodríguez-Pose and Palavicini-Corona [96] highlight the different effects on economic and social well-being according to the behavior of the institutions: in those cases where they promote the participation of citizens in the design, implementation and evaluation of initiatives, local development policy has a greater impact than in the municipalities where such local actions are politicized.

In the framework of promoting endogenous development, it is necessary to consider that social economy enterprises act as agents of development $[17,21,97]$ from different perspectives such as job creation, population fixation, poverty reduction, economic, social and territorial cohesion, increased efficiency of public policies, the extension of citizen participation, and sustainable development $[24,25,27-29,32,98-103]$. Thus, such companies, which have a democratic structure based on a participatory basis and cooperative values [104] are closely linked to the territory [105]. This allows them to integrate the needs and concerns of the environment [22], taking into account its specific circumstances (social, environmental and cultural), while acting as dynamizing agents of local resources [106]. In addition, their activity is linked to a specific area which favors, on the one hand, the creation of networks capable of strengthening the social and economic relations of local actors [107], and, on the other hand, the reinvestment of profits causing a multiplier effect on the generation of wealth, employment, and economic activity [16], bringing added value to the local development process $[108,109]$. In this way, social economy companies play a key role as service providers in those areas that are less attractive, economically speaking, for the rest of the for-profit companies [110].

Likewise, institutions of cooperative and collective origin create economic activity and employment [111], as they favor both the creation of other companies in the different sectors of economic activity (highlighting activities such as agriculture, financial intermediation, commercial distribution, associated work, services and construction) [112], as well as the creation of stable and quality jobs $[101,113,114]$ or the agricultural restructuring, modernization and industrialization of the productive fabric in rural areas [115]. In this way, they contribute to the correction of labor market imbalances, as well as to the generation and diversification of the business fabric [32,116], meeting the needs of their partners and other stakeholders (other cooperatives, the unemployed, suppliers, clients, and other actors) [20]. All this is carried out through the creation of indefinite jobs and the inclusion of diverse and inclusive staff $[117,118]$. These strengths have been demonstrated during the recessive period, when while the rest of the capitalist companies decimated employment levels, they maintained and even increased pre-crisis employment levels, highlighting their ability to maintain and generate employment in recession cycles [119] thus cushioning the harmful effects of the crisis $[120,121])$. Similarly, thanks both to their own cooperative characteristics and principles [20], and to their lower financial dependence [33] they have become an instrument for the recovery of companies declared bankrupt after the last financial crisis [122].

Social economy organizations, as territorial development actors, also contribute to sustainable development, which is positioned as a support axis of local development policies $[20,21]$ because of its own values, principles, and characteristics. Specifically, the collaboration of these companies with sustainable development is expressed through their principle of "interest in the community" [123]. In this sense, they participate in the maintenance of local economic activity, giving priority to environmental activities, and 
generate/reinvest wealth in their environment by helping to improve economic, social, and environmental cohesion, which highlights their commitment both to the community and to the environment [124]. As a consequence of all of the above, social economy companies collaborate in anchoring the population to the territory $[18,26,34,125]$

In short, the bottom-up vision, taken by the social economy, drives development processes by placing local actors as a strategic element in local initiatives, which increases the efficiency of public policies [126] as citizens participate in their design and management, shaping them according to their needs.

In this context, and considering all of the above, we could question how the existence of social economy companies would affect the sustainability of the population through business growth and job creation, giving rise to the following hypotheses:

Hypothesis 11 (H11). The greater the presence of social economy entities in a territory, the greater the number of economic activities and the better is the functioning of the labor market, thus helping to anchor population in the area.

Hypothesis 12 (H12). The greater the presence of social economy entities in each territory, the greater the vegetative growth and the greater the population level.

Derived from the raised hypotheses, the theoretical model is presented (Figure 1), which allows us to see the relationships considered previously.

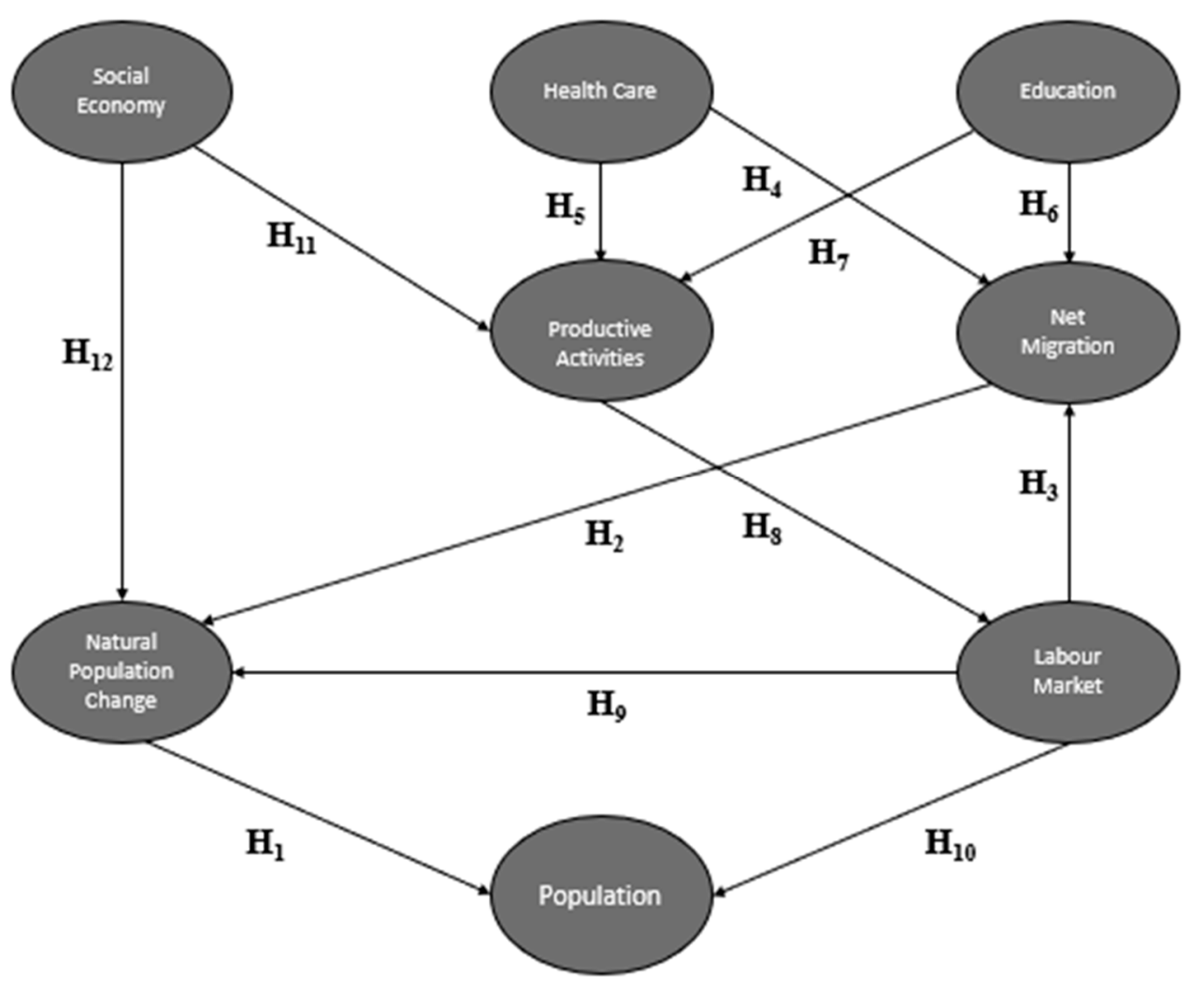

Figure 1. Theoretical model.

\section{Materials and Methods}

To test our hypotheses, we defined a structural equation model (SEM), following the partial least squares (PLS) method. This technique is appropriate for causal-predictive analysis when there is insufficient theoretical information. It enables latent variables to be estimated (weighting the components of the constructs) and multiple regressions to be conducted, determining the paths between the exogenous and endogenous constructs [127]. 
In other words, it permits dependence relationships to be established between constructs or variables that are not directly measurable $[128,129]$. Moreover, it can be used to simultaneously estimate mediator and moderator effects with multiple constructs [130].

Furthermore, PLS perfectly suits the data used and the variables included in the model, which are both characterized by their heterogeneity. Our model was configured in nine constructs, tied to 21 indicators derived from data on the 613 municipalities in the provinces of Albacete, Cuenca, and Guadalajara (Castilla-La Mancha, Spain) for 2017 and 2018. Within the model, the endogenous construct (population) is explained by eight exogenous constructs, of which two are direct (natural population change and labor market) and six indirect (productive activities, social economy, education, net migration, health care and foreign population).

Table 1 shows the variables defined in the model, the factors that comprise them and their sources.

Table 1. Constructs, Variables and Sources.

C1 Population

Total population (TP)

C2 Natural population change

\begin{tabular}{lll}
\hline Births (BIR) & Number of births in 2018 & http:/ / ine.es (accessed on 20 November 2020) \\
\hline Deaths (DEA) & Number of deaths in 2018 & http:/ / ine.es (accessed on 20 November 2020) \\
\hline C3 Education & & \\
\hline
\end{tabular}

Primary Schools (PS)

Number of primary education schools

http:/ / www.ies.jccm.es (accessed on 20 November 2020)

Secondary Schools and Vocational Training Schools (SS and VTS)

Number of schools providing compulsory secondary education, baccalaureate and vocational training

http:/ / www.ies.jccm.es (accessed on 20 November 2020)

C4 Productive Activities

Wholesale Trade (WT)

Number of companies in this sector by municipality

https: / / datosabiertos.castillalamancha.es (accessed on 20 November 2020)

Number of companies in this sector https://datosabiertos.castillalamancha.es by municipality (accessed on 20 November 2020)

Retail Trade (RT)

Number of companies in this sector by municipality

https: / / datosabiertos.castillalamancha.es (accessed on 20 November 2020)

Number of companies in this sector https://datosabiertos.castillalamancha.es by municipality (accessed on 20 November 2020)

Number of companies in this sector https:/ datosabiertos.castillalamancha.es by municipality (accessed on 20 November 2020)

Number of companies in this sector https://datosabiertos.castillalamancha.es by municipality (accessed on 20 November 2020)

Number of hectares available for crop-growing

http:/ / www.ies.jccm.es (accessed on 20 November 2020)
Utilized Agricultural Area (UAA)

C5 Net Migration

Inflow (INF)

Outflow (OUT)
Number of immigrants to the region, both internal and external

http:/ / www.ies.jccm.es (accessed on 20 November 2020)

Number of emigrants from the region, http:/ / www.ies.jccm.es (accessed on 20 both internal and external

November 2020) 
Table 1. Cont.

\begin{tabular}{lll}
\hline C6 Health care & $\begin{array}{l}\text { Health centers by municipality } \\
\text { (without emergency services) }\end{array}$ & $\begin{array}{l}\text { https://datosabiertos.castillalamancha.es } \\
\text { (accessed on 20 November 2020) }\end{array}$ \\
\hline Minutes (MIN) & $\begin{array}{l}\text { Distance in minutes to the nearest } \\
\text { emergency service }\end{array}$ & $\begin{array}{l}\text { https://datosabiertos.castillalamancha.es } \\
\text { (accessed on 20 November 2020) } \\
\text { https://www.google.com/maps (accessed on 20 } \\
\text { November 2020) }\end{array}$ \\
\hline C7 Social Economy & $\begin{array}{l}\text { Number of special employment } \\
\text { centers by municipality, 2018 }\end{array}$ & $\begin{array}{l}\text { https://datosabiertos.castillalamancha.es } \\
\text { (accessed on 20 November 2020) }\end{array}$ \\
\hline Special Employment Centers (SEC) & $\begin{array}{l}\text { Number of employment integration } \\
\text { companies by municipality, 2018 }\end{array}$ & $\begin{array}{l}\text { https://datosabiertos.castillalamancha.es } \\
\text { (accessed on 20 November 2020) }\end{array}$ \\
\hline $\begin{array}{l}\text { Employment Integration } \\
\text { Companies (EIC) }\end{array}$ & $\begin{array}{l}\text { Number of active cooperatives by } \\
\text { municipality, 2018 }\end{array}$ & \begin{tabular}{l} 
Registro de Cooperativas \\
\hline Cooperatives (COOP)
\end{tabular} \\
\hline C8 Labor Market & $\begin{array}{l}\text { Number of job contracts per } \\
\text { municipality in 2018 }\end{array}$ & $\begin{array}{l}\text { http://www.ies.jccm.es (accessed on 20 } \\
\text { November 2020) }\end{array}$ \\
\hline Job Contracts (CONT) & $\begin{array}{l}\text { Registered unemployment per } \\
\text { municipality in 2018 }\end{array}$ & $\begin{array}{l}\text { http://www.ies.jccm.es (accessed on 20 } \\
\text { November 2020) }\end{array}$ \\
\hline Registered Unemployment (RE)
\end{tabular}

\section{Results and Discussion}

The model was evaluated in three stages. In the first, we verified the individual reliability of the items, where all factor loadings should be higher than $0.7[130,131]$. We then tested the internal consistency, and the convergent and discriminant validity of the constructs [132]. The internal consistency, which provides information on the reliability of each of the constructs in the model, was analyzed by means of Cronbach's alpha and the composite reliability, accepting values above 0.7 for the first criterion and 0.6 for the second [133]. Convergent validity shows to what degree a set of indicators represents one and the same underlying construct [127]. To do this, we calculated the average variance extracted (AVE), which should be equal to or above 0.5 , meaning that each construct or variable explains at least $50 \%$ of the variance of the indicators. In the proposed model, all the items met the standard criteria (Table 2), which confirms that all the indicators share more variance with their construct than with the other constructs hypothesized in the model. Finally, divergent validity establishes whether indicators are related to the construct in which they are included. According to Barclay et al., [132] factor loadings should be higher when compared with their own variables than with the other variables, that is, factor loadings should be higher than cross-loadings.

Table 2. Indicators of Validity and Reliability.

\begin{tabular}{llccc}
\hline & AVE & Composite Reliability & Cronbachs Alpha & $\mathbf{R}^{2}$ \\
\hline C1 & 1.000 & 1.000 & 1.000 & 0.982 \\
\hline C2 & 0.991 & 0.995 & 0.991 & - \\
\hline C3 & 0.938 & 0.979 & 0.967 & - \\
\hline C4 & 0.814 & 0.968 & 0.960 & - \\
\hline C5 & 0.994 & 0.997 & 0.994 & - \\
\hline C6 & 0.707 & 0.827 & $\mathbf{0 . 6 1 6}$ & - \\
\hline C7 & 0.850 & 0.944 & 0.912 & - \\
\hline C8 & 0.948 & 0.974 & 0.948 & \\
\hline
\end{tabular}


Based on Table 2, we noted that the health construct did not meet the internal consistency assessment criterion through the Cronbach alpha being below 0.7. Consequently, it was decided to eliminate these variables in order to achieve a much more refined model that allowed us to confirm or reject the main hypotheses. Thus, once the health construct was eliminated, we obtained a new model (Figure 2) for which we repeated the analysis of internal consistency and convergent validity, continuing with the study of discriminant validity, which gave us information on how the indicators were related to the construct where they were contained. Figure 2 shows the model obtained using the statistical analysis software Smart PLS 2.0. It includes the causal relationships between the latent variables, the factor loadings of each indicator, the path coefficients, and the $R^{2}$ of each construct.

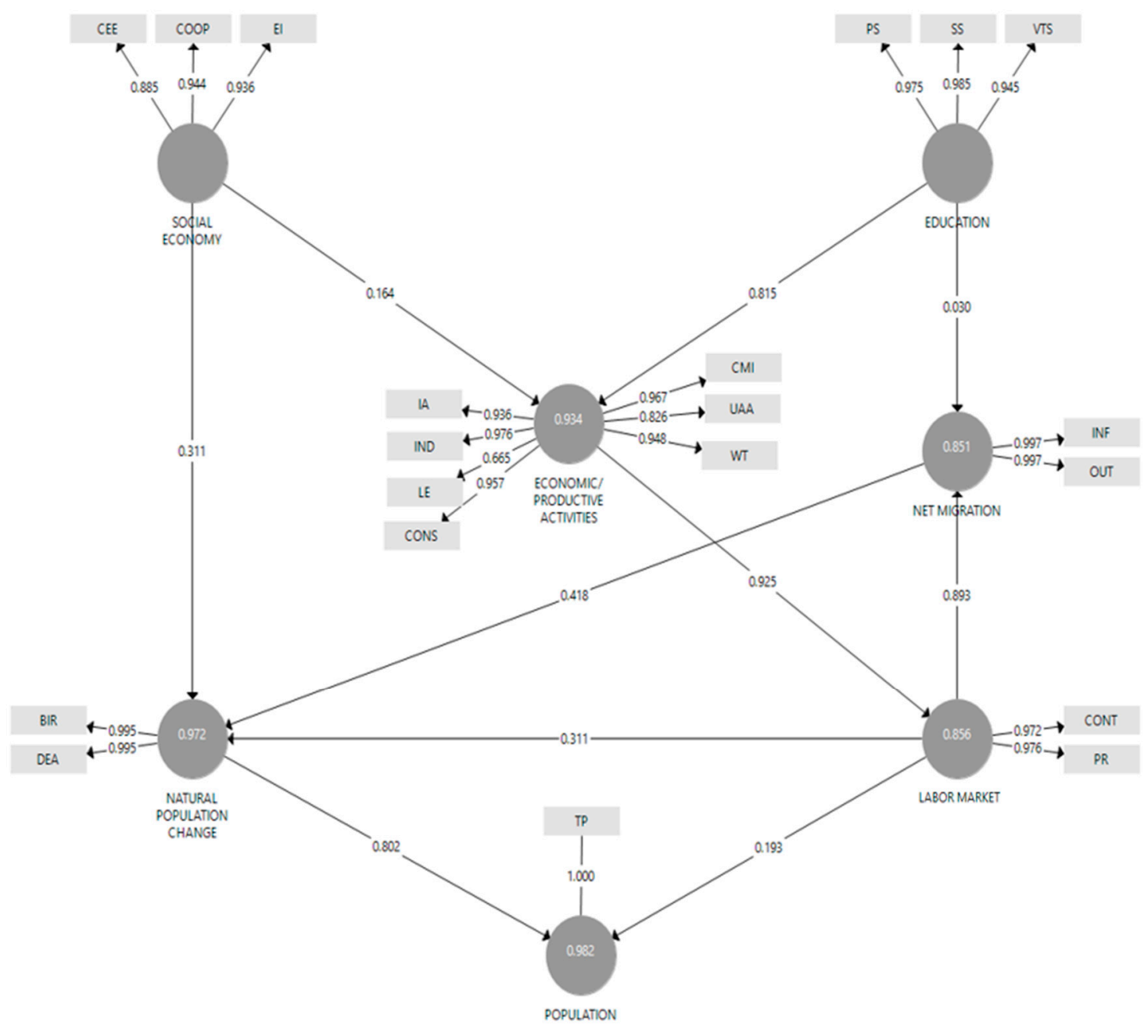

Figure 2. Results of Model 2.

The variables used in the last model meet the criteria of internal consistency (Cronbach's alpha and composite reliability) and discriminant validity (cross-load criterion). Furthermore, the algebraic sign of the coefficients shows the direction of the relationships between the exogenous variables and the endogenous variable. The path coefficients, the values for which should be between one and minus one, indicate the strength of the relationships, with these relationships being stronger the closer the value is to one.

Finally, we used the bootstrapping technique to verify the significance of the relationships [130], finding that all the relationships considered in our second model, except education with net migration, are significant (Table 3). The final step in the analysis was to calculate the $\mathrm{R}^{2}$, which provides information on the explanatory power of a model [132]. Although, in principle, this indicator has no acceptance limit, authors such as Chin [131] 
consider that $R^{2}$ below 0.67 is substantial, $R^{2}$ below 0.33 is moderate, and $R^{2}$ below 0.10 is weak. Similarly, Falk and Miller [134] state that $R^{2}$ should be higher than 0.10 , in such a way that the exogenous variables explain at least $10 \%$ of the endogenous variable.

Table 3. Indicators of Validity and Reliability of Model 2.

\begin{tabular}{|c|c|c|c|c|c|c|c|c|}
\hline & \multicolumn{2}{|c|}{ AVE } & \multicolumn{3}{|c|}{ Composite Reliability } & \multicolumn{2}{|c|}{ Cronbach's Alpha } & $\mathbf{R}^{2}$ \\
\hline $\mathrm{C} 1$ & \multicolumn{2}{|c|}{1.000} & \multicolumn{3}{|c|}{1.000} & \multicolumn{2}{|c|}{1.000} & 0.982 \\
\hline $\mathrm{C} 2$ & \multicolumn{2}{|c|}{0.991} & \multicolumn{3}{|c|}{0.995} & \multicolumn{2}{|c|}{0.991} & 0.972 \\
\hline $\mathrm{C} 3$ & \multicolumn{2}{|c|}{0.938} & \multicolumn{3}{|c|}{0.979} & \multicolumn{2}{|c|}{0.967} & - \\
\hline $\mathrm{C} 4$ & \multicolumn{2}{|c|}{0.814} & \multicolumn{3}{|c|}{0.968} & \multicolumn{2}{|c|}{0.960} & 0.934 \\
\hline C5 & \multicolumn{2}{|c|}{0.994} & \multicolumn{3}{|c|}{0.997} & \multicolumn{2}{|c|}{0.994} & 0.851 \\
\hline $\mathrm{C} 7$ & \multicolumn{2}{|c|}{0.850} & \multicolumn{3}{|c|}{0.944} & \multicolumn{2}{|c|}{0.912} & - \\
\hline $\mathrm{C} 8$ & \multicolumn{2}{|c|}{0.948} & \multicolumn{3}{|c|}{0.974} & \multicolumn{2}{|c|}{0.946} & 0.856 \\
\hline \multicolumn{9}{|c|}{ Loading and cross-loading matrix } \\
\hline & \multicolumn{2}{|c|}{ C4 } & $\mathrm{C} 3$ & $\mathrm{C} 8$ & $\mathrm{C} 2$ & C5 & $\mathrm{C} 1$ & $\mathrm{C} 7$ \\
\hline BIR & \multicolumn{2}{|c|}{0.942} & 0.980 & 0.982 & 0.995 & 0.941 & 0.990 & 0.906 \\
\hline CEE & & & 0.722 & 0.712 & 0.710 & 0.535 & 0.711 & 0.885 \\
\hline CMI & & & 0.988 & 0.967 & 0.994 & 0.902 & 0.983 & 0.912 \\
\hline CONS & & & 0.975 & 0.957 & 0.992 & 0.921 & 0.979 & 0.891 \\
\hline CONT & & & 0.888 & 0.972 & 0.907 & 0.907 & 0.912 & 0.803 \\
\hline COOP & & & 0.892 & 0.851 & 0.857 & 0.682 & 0.859 & 0.944 \\
\hline DEA & & & 0.974 & 0.956 & 0.995 & 0.921 & 0.981 & 0.881 \\
\hline EI & & & 0.892 & 0.889 & 0.902 & 0.815 & 0.909 & 0.936 \\
\hline IA & & & 0.853 & 0.790 & 0.819 & 0.671 & 0.795 & 0.805 \\
\hline IND & & & 0.964 & 0.927 & 0.941 & 0.826 & 0.932 & 0.878 \\
\hline INF & & & 0.909 & 0.936 & 0.945 & 0.997 & 0.943 & 0.767 \\
\hline $\mathrm{LE}$ & & & 0.510 & 0.440 & 0.489 & 0.373 & 0.455 & 0.455 \\
\hline OUT & & & 0.873 & 0.903 & 0.919 & 0.997 & 0.913 & 0.711 \\
\hline PR & & & 0.993 & 0.976 & 0.986 & 0.891 & 0.983 & 0.928 \\
\hline PS & & & 0.975 & 0.956 & 0.980 & 0.904 & 0.973 & 0.884 \\
\hline SS & & & 0.985 & 0.951 & 0.973 & 0.885 & 0.966 & 0.892 \\
\hline $\mathrm{TP}$ & & & 0.974 & 0.974 & 0.990 & 0.931 & 1.000 & 0.902 \\
\hline UAA & & & 0.697 & 0.645 & 0.675 & 0.527 & 0.673 & 0.701 \\
\hline VTS & & & 0.945 & 0.902 & 0.897 & 0.805 & 0.888 & 0.873 \\
\hline WT & & & 0.959 & 0.944 & 0.946 & 0.814 & 0.952 & 0.950 \\
\hline & & & dividu & lificance & variabl & & & \\
\hline & Hypothesis & $\begin{array}{c}\text { Path } \\
\text { coefficients }\end{array}$ & & $T$ Value & & & & Decision \\
\hline $\mathrm{C} 4 \rightarrow \mathrm{C} 8$ & H8 & 0.925 & & $21.233^{* * *}$ & & & & Supported \\
\hline $\mathrm{C} 3 \rightarrow \mathrm{C} 4$ & $\mathrm{H7}$ & 0.815 & & $9.990^{* * *}$ & & & & Supported \\
\hline $\mathrm{C} 3 \rightarrow \mathrm{C} 5$ & $\mathrm{H} 6$ & 0.030 & & 0.109 & & & & $\begin{array}{c}\text { Not } \\
\text { Supported }\end{array}$ \\
\hline $\mathrm{C} 8 \rightarrow \mathrm{C} 2$ & H9 & 0.311 & & 1.547 * & & & & Supported \\
\hline
\end{tabular}


Table 3. Cont.

\begin{tabular}{lccccc}
\hline $\mathrm{C} 8 \rightarrow \mathrm{C} 5$ & $\mathrm{H} 3$ & 0.893 & $3.304^{* * *}$ & 0.001 & 0.019 \\
\hline $\mathrm{C} 8 \rightarrow \mathrm{C} 1$ & $\mathrm{H} 10$ & 0.193 & $2.347^{* * *}$ & 0.000 & Supported \\
\hline $\mathrm{C} 2 \rightarrow \mathrm{C} 1$ & $\mathrm{H} 1$ & 0.802 & $9.577^{* * *}$ & 0.001 & Supported \\
\hline $\mathrm{C} 5 \rightarrow \mathrm{C} 2$ & $\mathrm{H} 2$ & 0.418 & $3.325^{* * *}$ & 0.062 & Supported \\
\hline $\mathrm{C} 7 \rightarrow \mathrm{C} 4$ & $\mathrm{H} 11$ & 0.164 & $1.867^{* *}$ & 0.015 & Supported \\
\hline $\mathrm{C} 7 \rightarrow \mathrm{C} 2$ & $\mathrm{H} 12$ & 0.311 & $2.446^{* * *}$ & Supported \\
\hline
\end{tabular}

\section{Mediation analysis:}

Additionally, PLS as any structural equation modeling program can produce estimates of the coefficients in a mediation model. The mediation analysis (described in Hayes [135]) assumes that if the mediator variable $(\mathrm{M})$ is located between two other variables $(X$ and $\mathrm{Y})$, then, $\mathrm{X}$ causes $\mathrm{M}$ and $\mathrm{M}$ causes $\mathrm{Y}$. This type of indirect effect can be extended to a model with any number of mediators working in parallel. In our case, we find four mediating variables: net population growth, net migration, productive activities, and the labor market. They weave a network of indirect relationships and mediating effects. In order to analyze the indirect effect that the social economy has on the population, the bootstrapping technique (with 500 re-sample) is performed. It provides us with information on the indirect effect of the proposed relationships, confidence intervals and significance. For the proposed model, the indirect relationships between the social economy and the labor market will be significant $(\beta=0.152$, $t$-value $=2.079)$, as well as social economy and population $(\beta=0.362$, $t$-value $=3.379)$, and social economy and vegetative growth $(\beta=0.104, t$-value $=1.750)($ see Table 4$)$.

Table 4. Results of social economy indirect relationships.

\begin{tabular}{ccccc}
\hline Hypothesis & Indirect Effect & Confidence Interval & $\boldsymbol{t}$-Value & $\boldsymbol{p}$-Value \\
\hline $\mathrm{C} 7 \rightarrow \mathrm{C} 8$ & 0.152 & $(0.018,0.302)$ & 2.079 & $0.038^{* * *}$ \\
\hline $\mathrm{C} 7 \rightarrow \mathrm{C} 2$ & 0.104 & $(0.008,0.237)$ & 1.750 & $0.081^{* *}$ \\
\hline $\mathrm{C} 7 \rightarrow \mathrm{C} 5$ & 0.136 & $(0.011,0.353)$ & 1.482 & 0.139 \\
\hline $\mathrm{C} 7 \rightarrow \mathrm{C} 1$ & 0.362 & $(0.095,0.535)$ & 3.379 & $0.001^{* * *}$ \\
\hline & $* * 0.05 ; * * 0.01$.
\end{tabular}

The analysis conducted confirms all the hypotheses proposed in the theoretical model, except H4, H5 and H6. The fact that the model does not allow us to contrast these hypotheses does not mean that the hypotheses are not true, merely that we cannot test them with our model. In the case of the first two hypotheses, they had to be extracted from the model because the construct designed did not meet the minimum requirements of the first step of the analysis, and in the case of the third one, it was because the resulting coefficient was not significant.

As predicted by the literature [48,49], demographic factors are directly related to the population of a territory; the lower the difference between the number of deaths and births, the smaller the decline in the total number of inhabitants. In the same way, net migration has a positive effect on total population: the greater the net migration, the lower the loss of population, or, in other words, the larger the overall population [51].

Improving the provision of educational services has a positive effect on economic growth and the generation of job opportunities. Social services are, in addition, an instrument for local development, especially in the less populated municipalities where there are other added difficulties, such as the greater isolation of rural areas, both from the point of view of new technologies, such as broadband internet, as well as physical transport 
infrastructures. These facts hinder the population's mobility and access to information, so the role of rural schools is more than justified.

Currently, distance training opens up a world of hitherto unknown possibilities, which, however, cannot be analyzed in our model because there is no information in this regard. In addition, it would need the provision of services and communication infrastructures, which the most remote spaces lack. It will be interesting to study the consequences for education of the actions to digitize the rural world that are intended to be promoted with the new "Next Generation" cohesion fund package, and programs such as the "Recovery and Resilience Plan" in Spain.

With regard to the labor market, our results show that in territories with more dynamic employment opportunities, the population is higher, which is a direct consequence of the positive relationship between these two variables. Thus, the labor market, in the same way as education services, attracts and increases population size. Our model reveals a direct, positive relationship between the labor market and productive activities, and a positive, indirect relationship between the labor market and social economy, but, as the literature explains, the relationships between economic activity and the size/quality of the labor market are bidirectional, with causation (and not only correlation) in both directions. Unfortunately, PLS does not allow us to design these types of relationships; besides, the relationships between economic activity and employment are a deep and complex field of study that we cannot address in this paper. As the objective of this article is not to analyze the labor market but to establish the relationships between social economy and population, we have specified causality between productive activity and the labor market in a single direction, according to the main hypotheses that we wanted to demonstrate, looking for possible mediation relationships through the variables (constructs) that affect the size of the population, which are, according to the theory, vegetative growth and migratory movements. That is why the constructs have been defined in this way: what retains and attracts population to a territory is the existence of job opportunities, which are the consequence of vibrant economic activity. These variables have been proved to act as mediating variables between the social economy and the population.

Following the theoretical framework proposed, social economy entities act as development agents in rural and depressed areas $[17,21]$ through the generation of economic activity [111]. This, in turn, allows the emergence of new companies in the different sectors of economic activity [112], strengthening the economic and social relations of the actors involved [23,107], and favoring the process of modernization and industrialization of the productive fabric [114], as well as the diversification of the business fabric $[32,116]$. Similarly, they act on job creation [101,113]), and thus on an improvement of the labor market, collaborating both in the livelihood of local economic activity, as well as in the resilience of the population $[18,26,125]$. As the literature shows, social economy companies, due to their particular characteristics, serve greater local and endogenous development, avoiding the capitalist logic of other companies, which are angled toward the installation of economic activity in those places where the greatest benefit is expected to be obtained. For this reason, economic growth is not homogeneous, and some spaces grow (both economically and in population size) while others are depopulated due to a lack of job opportunities.

In short, the proposed model confirms that demographic factors (natural population change and net migration) are those most intensely associated with population settlement, but the economic conditions of the territory, that is, the economic dynamism of the area and the employment opportunities, are also determinants of this process. In this context, social economy entities are also key as they support the creation of enterprises in different sectors, directly and indirectly influencing the generation of sources of business and employment and encouraging local and economic development.

\section{Conclusions}

The present work had the objective of determining the contribution that social economy organizations make with regard to local development and population fixation in the 
provinces of Albacete, Cuenca, and Guadalajara (Castilla-La Mancha, Spain). To achieve this goal, a theoretical model is presented, which includes the hypotheses raised after the literature review, and two different econometric studies based on the partial least squares (PLS) methodology, through which the factors affecting the size of the population are identified.

Depopulation has become a first-order problem, affecting with the greatest intensity the small municipalities of rural Spain, where $80 \%$ of the municipalities of Castilla-La Mancha are located. In an eminently rural region, and facing a serious depopulation problem, this study has allowed us to demonstrate, according to the literature, that the existence of social economy entities is a factor in mobilizing local productive resources, which favors economic activity in different sectors of activity and the generation of stable and quality employment, which helps to fix the population in these territories and increase their resilience.

The model allows us to confirm that the demographic factors (vegetative growth and migratory balance) have a greater effect in the setting of the population; however, they are also the economic conditions of the territory, that is, the economic dynamism of the area and employment opportunities, which have a decisive influence on this process. In this context, the social economy institutions take on a greater role by acting as a support pillar in the creation of companies in the different sectors, thus influencing the creation of business and employment sources, favoring economic and local development, attracting, and retaining the population.

Finally, it is worth highlighting the limitations of the present work, derived from the static nature of the econometric model, which makes it difficult to analyze the evolution of both demographic and economic factors. However, a relevant conclusion in terms of economic policy can be drawn: urgent action from the public administration is undoubtedly needed, action which should focus on local and regional development policies for rural areas (policies that encourage young farmers to set up businesses, programs to promote the diversification of economic activity, etc.). Thus, taking into account the benefits of social economy entities (settlement of the population, local development, wealth generation, enhanced quality of life, etc.), the present study highlights the need to invest efforts in these types of companies in rural areas, passing laws and updating the current legislation to strengthen the presence of such enterprises.

The results open new avenues of research to complete and expand them, for example, to territorial synergies between innovation and social economy, linked to environmental and/or institutional aspects. In this sense, to explain the importance of social economy enterprises in the local development process and consequently in population fixation, on the one hand, we propose the so-called hedonic models that would explain the characteristics of companies in terms of their structure, economic activity and location; and on the other hand, territorial gravitational models would be detailed to identify the size of the attraction that these companies exert in the population, either withholding it or making a called effect.

Author Contributions: Conceptualization, I.C. and M.C.; methodology, M.C., I.C. and M.C.G.-C.; software, M.C.; validation, M.C.; formal analysis, I.C. and S.C.; data curation, M.C.; writing-original draft preparation, I.C.; writing-review and editing, I.C. and S.C.; project administration, I.C.; All authors have read and agreed to the published version of the manuscript.

Funding: This research was funded by University of Castilla La Mancha-ESF, grant number 2020GRIN-29121.

Institutional Review Board Statement: No applicable.

Informed Consent Statement: No applicable.

Data Availability Statement: Data are public and links are contained into the text.

Conflicts of Interest: The authors declare no conflict of interest. 


\section{References}

1. Johnson, K.; Layton, F.; Dudley, P. More Deaths than Births: Subnational Natural Decrease in Europe and the United States. Popul. Dev. Rev. 2015, 41, 651-680. [CrossRef]

2. Camarero, L.; Sampedro, R. Despoblación y Ruralidad Transnacional: Crisis y Arraigo Rural en Castilla y León. Econ. Agrar. Recur. Nat. 2019, 19, 59-82. [CrossRef]

3. Collantes, F.; Pinilla, V. Peaceful Surrender: The Depopulation of Rural Spain in the Twentieth Century; Cambridge Scholars Publishing: Newcastle-upon-Tyne, UK, 2011.

4. Haider, L.J.; Boonstra, W.J.; Peterson, G.D.; Schlüter, M. Traps and Sustainable Development in Rural Areas: A Review. World Dev. 2018, 101, 311-321. [CrossRef]

5. Lowe, P.; Phillipson, J.; Proctor, A.; Gkartzios, M. Expertise in Rural Development: A Conceptual and Empirical Analysis. World Dev. 2019, 116, 28-37. [CrossRef]

6. Surchev, P. Rural Areas, Problems and Opportunities for Development. Trakia J. Sci. 2010, 8, 234-239.

7. Rajovig, G.; Bulatovic, J. Charateristics of Housing in Rural Villages: The Case Northeastern Montenegro. Int. Lett. Soc. Humanist. Sci. 2013, 6, 24-35.

8. Haub, C.; Toshiko, K. World Population Data Sheet; Population Reference Bureau: Washington, DC, USA, 2014.

9. Spanish Centre for Sociological Research (CIS): Barómetro de Febrero 2019. Available online: Datos.cis.es/pdf/Es3240mar_A.pdf (accessed on 2 March 2021).

10. Gutiérrez, E.; Moral-Benito, E.; Ramos, R. Tendencias Recientes de la Población en las Áreas Rurales y Urbanas de España; Banco de España: Madrid, Spain, 2020.

11. Ministerio para la Transición Ecológica y el Reto Demográfico. El Reto Demográfico y la Despoblación en Cifras. 2020. Available online: 280220-despoblacion-en-cifras.pdf (accessed on 20 March 2021).

12. Johnson, K.M.; Lichter, D.T. Rural Depopulation: Growth and Decline Processes over the Past Century. Rural Sociol. 2019, 84, 3-27. [CrossRef]

13. Vázquez-Barquero, A. Desarrollo Local, una Estrategia para Tiempos de Crisis. Apunt. CENES 2009, 28, 117-132.

14. Rodríguez-Cohard, J.C. Los Procesos de Desarrollo Local Desde la Perspectiva Europea: Génesis y Transformación. Semest. Económico 2009, 12, 37-55.

15. Gertler, M.S. Rules of the Game: The Place of Institutions in Regional Economic Change. Reg. Stud. 2010, 44, 1-15. [CrossRef]

16. Morales-Gutiérrez, A.C. La Construcción de Capital Social a Través de la Economía Social: El Caso Andaluz. REVESCO Rev. Estud. Coop. 2002, 78, 89-120.

17. Juste, J.J.; Gómez, J.M.; Fernández, J.E. Economía Social y Desarrollo Local/Rural. Un Análisis de sus Sinergias. Estud. Econ. Apl. 2011, 29, 189-221.

18. Buendía-Martínez, I.; Côté, A. Desarrollo Territorial Rural y Cooperativas: Un Análisis Desde las Políticas Públicas. Cuad. Desarro. Rural 2014, 2, 35-54. [CrossRef]

19. Mozas, A.; Bernal, E.; Fernández, D.; Medina, M.J. Sostenibilidad, Desarrollo Endógeno y Economía Social. Rev. Iberoam. Econ. Solidar. Innovación Socioecológica 2020, 3, 17-35. [CrossRef]

20. Poyatos, R.P.; Gámez, M.D.M.V. Importancia de las Sociedades Cooperativas como Medio para Contribuir al Desarrollo Económico, Social y Medioambiental, de Forma Sostenible y Responsable. REVESCO Rev. Estud. Coop. 2009, 99, 104-129.

21. Mozas, A.; Bernal, E. Economía Social y Desarrollo Rural. CIRIEC España Rev. Econ. Pública Soc. Coop. 2006, 55, 125-140.

22. Pérez de Mendiguren, J.C.; Etxezarreta, E.; Guridi, L. Economía Social, Empresa Social y Economía Solidaria: Diferentes Conceptos para un Mismo Debate. Pap. Econ. Solidar. 2009, 1, 1-41.

23. Fajardo García, G.; Escribano Pizarro, J. Despoblamiento y Desarrollo Rural. Propuestas de la Economía Social; CIRIEC-España: Valencia, Spain, 2020.

24. Bel Durán, P.; Cabaleiro Casal, M.J. La Sociedad Cooperativa: Fórmula Empresarial Idónea para el Desarrollo Rural Endógeno y Sostenible. Rev. Española Estud. Agrosoc. Pesq. 2002, 194, 9-25.

25. Mhembwe, S.; Dube, E. The Role of Cooperatives in Sustaining the Livelihoods of Rural Communities: The Case of Rural Cooperatives in Shurugwi District, Zimbabwe. Jambá J. Disaster Risk Stud. 2017, 9, 1-9. [CrossRef]

26. Coque, J. Compartir Soluciones: Las Cooperativas como Factor de Desarrollo en Zonas Desfavorecidas; Consejo Económico y Social: Madrid, Spain, 2005.

27. Chaves, R.; Monzón, J.L. Beyond the Crisis: The Social Economy, prop of a New Model of Sustainable Economic Development. Serv. Bus. 2012, 6, 5-26. [CrossRef]

28. Castro, R.; Santero, R.; Martínez, M.I.; Guilló, N. Impacto Socioeconómico de las Empresas de Economía Social en España. Una Valoración Cuantitativa de sus Efectos Sobre la Cohesión Social. CIRIEC España Rev. Econ. Pública Soc. y Coop. 2013, 79 , 35-58.

29. Lukic, T.; Stojsavljevic, R.; Durdev, B.; Nad, I.; Dercan, B. Depopulation in the Western Balkan Countries. Eur. J. Geogr. 2012, 3, 6-23.

30. Herrero-Blasco, A. La Economía Social: Su función Económica y las Políticas Públicas de Fomento. RECERCA Rev. Pensam. Anàlisi 2014, 15, 77-91. [CrossRef]

31. Gómez, J.M.; Román, A. La Economía Social en Castilla y León: Un Sector Clave para Generar Empleo y Luchar Contra la Exclusión Social. Rev. Univ. Cienc. Trab. 2005, 5, 111-142. 
32. Melián, A.; Campos, V. Emprendedurismo y Economía Social como Mecanismos de Inserción Socio Laboral en Tiempos de Crisis. REVESCO Rev. Estud. Coop. 2010, 100, 43-67.

33. Birchall, J.; Ketilson, L. Resilience of the Cooperative Business Model in Times of Crisis; International Labor Organization: Geneva, Switzerland, 2009.

34. Valiente Palma, L. ¿Podría Estar Contribuyendo el Cooperativismo a Fijar la Población en el Territorio de Andalucía? CIRIEC España Rev. Econ. Publica Soc. Coop. 2019, 97, 49-74. [CrossRef]

35. Pinilla, V.; Ayuda, M.I.; Sáez, L.A. Rural Depopulation and the Migration Turnaround in Mediterranean Western Europe: A Case Study of Aragon. J. Rural Community Dev. 2008, 3, 1-22.

36. Envejecimiento, Despoblación y Territorio; López-Trigal, L.; Abellán, A.; Godenau, D. (Eds.) Universidad de León: León, Spain, 2009.

37. Van Bavel, J. Subreplacement Fertility in the West before the Baby Boom: Past and Current Perspectives. Popul. Stud. 2010, 64, 1-18. [CrossRef]

38. Escribano, J. El Valor de los Servicios Educativos y Sanitarios en los Procesos de Atracción y Mantenimiento de Población en Medio Rural. Ager. Rev. Estud. Despoblación Desarro. Rural 2012, 13, 11-51.

39. Green, A.; De Hoyos, M.; Jones, P.; Owen, D. Rural Development and Labour Supply Challenges in the UK: The Role of non-UK Migrants. Reg. Stud. 2008, 43, 1261-1273. [CrossRef]

40. Marré, A.W.; Rupasingha, A. School Quality and Rural In-migration: Can Better Rural Schools Attract New Residents? J. Reg. Sci. 2019, 1-19. [CrossRef]

41. Lovén, I.; Hammarlund, C.; Nordin, M. Staying or Leaving? The Effects of University Availability on Educational Choices and Rural Depopulation. Pap. Reg. Sci. 2020, 99, 1339-1365. [CrossRef]

42. Labrianidis, L.; Sykas, T. Migrants, Economic Mobility and Socio-economic Change in Rural Areas: The Case of Greece. Eur. Urban Reg. Stud. 2009, 16, 237-256. [CrossRef]

43. Collantes, F.; Pinilla, V.; Sáez, L.A.; Silvestre, J. Reducing Depopulation in Rural Spain: The Impact of Immigration. Popul. Space Place 2014, 20, 606-621. [CrossRef]

44. Coleman, D.; Rowthorn, R. Who's Afraid of Population Decline? A Critical Examination of Its Consequences. Popul. Dev. Rev. 2011, 37, 217-248. [CrossRef]

45. European Committee of the Regions. Opinion of the European Committee of the Regions: The EU Response to the Demographic Challenge. Off. J. Eur. Union 2017, 60, 40-45.

46. Pérez, A. Los Pequeños Municipios ante los Retos del Desarrollo. Norba. Rev. Geogr. 2006, 6, 183-197.

47. Gómez-Limón, J.A.; Atance, I.; Rico, M. Percepción Pública del Problema de la Despoblación del Medio Rural en Castilla y León. Ager Rev. Estud. Despoblación Desarro. Rural 2007, 6, 9-60.

48. Garrido, J.; Faci, Y. Causas de la Despoblación en la Cuenca del Río Guadalope: Comarcas del bajo Aragón y Maestrazgo Propuesta de Políticas Demográficas y de Desarrollo Endógeno. Inf. CEDDAR 2004, 1, 1-134.

49. Fernández, M.; Meixide, A. Declive Demográfico en Galicia y Territorio: El Diseño de Políticas Públicas en un Espacio Complejo y Heterogéneo; Universidad de Santiago de Compostela: Santiago de Compostela, Spain, 2013.

50. Carvajal, C. Efectos de las Migraciones en la Estructura por edad y Sexo de las Áreas Residenciales. In Envejecimiento, Despoblación y Territorio; López-Trigal, L., Abellán, A., Godenau, D., Eds.; Universidad de León: León, Spain, 2009; pp. 121-136.

51. Johnson, K.; Lichter, D. Diverging Demography: Hispanic and Non-Hispanic Contributions to US Population Redistribution and Diversity. Popul. Res. Policy Rev. 2016, 35, 705-725. [CrossRef]

52. Saco, A. Desarrollo Rural y Despoblación en Galicia. Rev. Estud. Despoblación Desarro. Rural 2010, 9, 11-30.

53. Godenau, D. Transformaciones Recientes de las Estructuras Poblacionales. In Envejecimiento, Despoblación y Territorio; López-Trigal, L., Abellán, A., Godenau, D., Eds.; Universidad de León: León, Spain, 2009; pp. 31-53.

54. Camarero, L.; Sampedro, R. ¿Por qué se van las Mujeres? El Continuum de Movilidad como Hipótesis Explicativa de la Masculinización Rural. Reis Rev. Española Investig. Sociológicas 2008, 124, 73-105.

55. Consejo Económico y Social de España, CES. El Medio Rural y se Vertebración Social y Territorial; Informe CES 1/2018; Consejo Económico y Social de España: Madrid, Spain, 2018.

56. Pérez, A.; Leco, F. Envejecimiento, Estancamiento Poblacional y Perspectivas Demográficas en Extremadura. Geographicalia 2011, 60, 309-321. [CrossRef]

57. Ellis, F. A Livelihoods Approach to Migration and Poverty Reduction; DFID, Paper Commissioned by the Department for International Development: London, UK, 2003.

58. Collantes, F.; Pinilla, V.; Sáez, L.A.; Silvestre, J. El Impacto Demográfico de la Inmigración en la España Rural Despoblada. Boletín Elcano 2010, 128, 1-28.

59. Camarero, L. La Sostenible Crisis Rural. Doc. Soc. 2009, 155, 13-22.

60. López, D.; Montoro, C.; Pons, J.J. El Papel Dinamizador de la Inmigración Internacional en el Crecimiento Demográfico de Navarra (1996-2006): Cuantificación y Valoración de la Realidad a Escala Municipal. In Actas del Séptimo Congreso de Economía de Navarra; Gobierno de Navarra, Fondo de Publicaciones: Pamplona, Spain, 2008; pp. 165-184.

61. Nieto, J.A. Incidencia de la Inmigración Extranjera en la Estructura Demográfica Andaluza. In La Inmigración Internacional: Motor de Cambios Sociodemográficos y Territoriales; EUNSA: Pamplona, Spain, 2008.

62. Cabré, A.; Moreno, J.; Pujadas, I. Cambio Migratorio y " Reconversión Territorial" en España. Reis Rev. Española Investig. Sociológicas 1985, 32, 43-65. [CrossRef] 
63. Pinilla, V.; Sáez, L.A. La Despoblación Rural en España: Génesis de un Problema y Políticas Innovadoras; Centro de Estudios sobre Despoblación y Desarrollo de Áreas Rurales (CEDDAR): Zaragoza, Spain, 2017.

64. Sampedro, R.; Camarero, L. Inmigrantes, Estrategias, Estrategias Familiares y Arraigo: Las Lecciones de la Crisis en las Áreas Rurales. Rev. Inst. Univ. Estud. Migr. 2016, 39, 3-31. [CrossRef]

65. Solé, A. Características Sociodemográficas, Pautas de Distribución Territorial y Proceso Migratorio de la Población; AGER Work Paper No. 29-2010; Centro de Estudios sobre la Despoblación y Desarrollo de Areas Rurales: Zaragoza, Spain, 2010.

66. Kasimimis, C. Demographic Trends in Rural Europe and International Migration to Rural Areas. Agriregionieuropa 2010, 21, 1-6.

67. Bachiller, J.M.; Molina, I. La Localización de Servicios y Equipamientos en el Medio Rural: Claves para la Articulación Territorial de Castilla y León. Ería Rev. Cuatrimest. Geogr. 2014, 93, 77-100.

68. Nechyba, T.J.; Strauss, R.P. Community Choice and Local Public Services: A Discrete Choice Approach. Reg. Sci. Urban Econ. 1997, 28, 51-73. [CrossRef]

69. Brereton, F.; Bullock, C.; Clinch, J.P.; Scott, M. Rural Change and Individual Well-being: The Case of Ireland and Rural Quality of Life. Eur. Urban Reg. Stud. 2011, 18, 203-227. [CrossRef]

70. Farmer, J.; Nimegeer, A.; Farrington, J.H.; Rodger, G. Rural Citizens' Rights to Accessible Health Services: An Exploration. Sociol. Rural. 2012, 52, 134-144. [CrossRef]

71. Van Lenthe, F.J.; Brug, J.; Mackenbach, J.P. Neighbourhood Inequalities in Physical Inactivity: The Role of Neighbourhood Attractiveness, Proximity to Local Facilities and Safety in the Netherlands. Soc. Sci. Med. 2005, 60, 763-775. [CrossRef] [PubMed]

72. Neumeier, S. Accessibility to Services in Rural Areas: The Example of Petrol Service Provision in Germany. disP Plan. Rev. 2016, 52, 32-49. [CrossRef]

73. Christiaanse, S. Rural Facility Decline: A Longitudinal Accessibility Analysis Questioning the Focus of Dutch Depopulation-policy. Appl. Geogr. 2020, 121, 102251. [CrossRef]

74. Castells, M. The Information Age: Economy. Society and Culture. In The Rise of the Network Society; Blackwell: Oxford, UK, 1996; Volume I.

75. Rodríguez-Pose, A. The Revenge of the Places That Don't Matter (and What to Do about It). Camb. J. Reg. Econ. Soc. 2018, 11, 189-209. [CrossRef]

76. Benito, L. Despoblación, Desarraigo y Escuela Rural. Encruc. Rev. Crítica Cienc. Soc. 2013, 6, 56-69.

77. Kroismayr, S. Small School Closures in Rural Areas: The Beginning or the End of a Downward Spiral? Some Evidence from Austria. In Studies in the Sociology of Population; Anson, J., Bartl, W., Kulczycki, A., Eds.; Springer Nature: Cham, Switzerland, 2019; pp. 275-300.

78. Kearns, R.A.; Lewis, N.; McCreanor, T.; Witten, K. The Status Quo is not an Option': Community Impacts of School Closure in South Taranaki, New Zealand. J. Rural Stud. 2009, 25, 131-140. [CrossRef]

79. Marré, A. Rural Education at a Glance, 2017 Edition; United States Department of Agriculture Economic Research Service: Washington, DC, USA, 2017.

80. Alburquerque, F. La Importancia del Enfoque del Desarrollo Económico Local. In Transformaciones Globales, Instituciones y Políticas de Desarrollo Local; Homo Sapiens: Rosario, Argentina, 2001; pp. 176-199.

81. Demirguc-Kunt, A.; Levine, R. Bank-Based and Market-Based Financial Systems-cross-Country Comparisons; Policy Research Working Paper Series 2143; World Bank Group: Washington, DC, USA, July 1999.

82. Escalona, A.I.; Díez, C. Despoblación Territorial y Oferta de Servicios: Diagnóstico y Propuestas. In Despoblación y Territorio; Centro de Estudios sobre la Despoblación y Desarrollo de Áreas Rurales: Zaragoza, Spain, 2007; pp. 61-118.

83. Carr, P.J.; Lichter, D.T.; Kefalas, M.J. Can Immigration Save Small-town America? Hispanic Boomtowns and the Uneasy Path to Renewal. Ann. Am. Acad. Political Soc. Sci. 2012, 641, 38-57. [CrossRef]

84. Autti, O.; Hyry-Beihammer, E.K. School Closures in Rural Finnish Communities. J. Res. Rural Educ. 2014, 29 , 1-17.

85. Jean, Y. École et Aménagement du Territoire Rural: Quel Avenir pour les Petites Structures Scolaires et les Communes Rurales? Ann. Géographie 1995, 104, 236-255. [CrossRef]

86. Witham, M. The Economics of (not) Closing Small Rural Schools. In Proceedings of the A Focus on Rural Issues' Symposium, Townsville, Australia, 30 June-2 July 1997.

87. Bryden, J.; Bollman, R. Rural Employment in Industrialised Countries. Agric. Econ. 2000, 22, 185-197. [CrossRef]

88. Vázquez Barquero, A. The New Forces of Development. Territorial Policy for Endogenous Development; World Scientific Publishing: Singapore, 2010.

89. Vázquez-Barquero, A. Las Nuevas Fuerzas del Desarrollo; Antonio Bosch Editor: Barcelona, Spain, 2005.

90. Alburquerque, F. Metodología para el Desarrollo Económico; ILPES/CEPAL: Santiago de Chile, Chile, 1997.

91. Vázquez-Barquero, A. Desarrollo Endógeno. Teorías y Políticas de Desarrollo Territorial. Investig. Reg. 2007, 11, 183-210.

92. Rodrik, D.; Subramanian, A.; Trebbi, F. Institutions Rule: The Primacy of Institutions over Geography and Integration in Economic Development. J. Econ. Growth 2014, 9, 131-165. [CrossRef]

93. Acemoglu, D.; Robinson, J.A. Why Nations Fail. The Origins of Power, Prosperity and Poverty; Crown Publishers: New York, NY, USA, 2012.

94. Vázquez Barquero, A.; Rodríguez Cohard, J.C. Endogenous Development and Institutions: Challenges for Local Development Initiatives. Environ. Plan. C Gov. Policy 2016, 34, 1135-1153. [CrossRef]

95. Burgos, A.L.; Bocco, G. Contributions to a Theory of Rural Innovation. Cuad. Econ. 2020, 39, 219-247. [CrossRef] 
96. Rodríguez-Pose, A.; Palavicini-Corona, E.I. Does Local Economic Development Really Work? Assessing LED across Mexican Municipalities. Geoforum 2013, 44, 303-315. [CrossRef]

97. Williamson, T.; Imbroscio, D.; Alperovitz, G. Making a Place for a Community: Local Democracy in a Global Era; Routledge: New York, NY, USA, 2003.

98. Van der Meer, T.W.; Van Ingen, E.J. Schools of Democracy? Disentangling the Relationship between Civic Participation and Political Action in 17 European Countries. Eur. J. Political Res. 2009, 48, 281-308. [CrossRef]

99. Carchano, M.; Carrasco, I.; Soler, F. El Papel de las Cooperativas de Crédito en el Sostenimiento de la España Vaciada a Través del Capital Social. REVESCO Rev. Estud. Coop. 2021, 138, 14-28.

100. Mammud, V. Rural Development in Nigeria: Concept, Approaches, Challenges and Prospects. Global Sci. J. 2019, 7, 444-459.

101. Perotin, V. Worker Cooperatives: Good, Sustainable Jobs in the Community. J. Entrep. Organ. Divers. 2013, 2, 34-47. [CrossRef]

102. Barea, J.; Monzón, J.L. Economía Social e Inserción Laboral de las Personas con Discapacidad en el País Vasco; Fundación BBVA: Bilbao, Spain, 2008.

103. Mozas, A.; Bernal, E.; Fernández, D.; Medina, M.J. Innovation as the Backbone of Sustainable Development Goal. Sustainability 2020, 12, 4747. [CrossRef]

104. Bauer, C.M.; Guzmán, C.; Santos, F.J. Social Capital as a Distinctive Feature of Social Economy Firms. Int. Entrep. Manag. J. 2012, 8, 437-448. [CrossRef]

105. Nilsson, J.; Svendsen, G.L.H.; Svendsen, G.T. Are Large and Complex Agricultural Cooperatives Losing Their Social Capital. Agribus. Int. J. 2012, 28, 187-204. [CrossRef]

106. Eversole, R.; Barraket, J.; Luke, B. Social Enterprises in Rural Community Development. Community Dev. J. 2013, 49, $245-261$. [CrossRef]

107. Buendía-Martínez, I.; Carrasco, I. The Role of CSR on Social Entrepreneurship: An International Analysis. Sustainability 2020, 12, 6976. [CrossRef]

108. Castro, M. La Economía Social como Agente Económico: Necesidad de su Participación en la Interlocución Social. CIRIEC España Rev. Econ. Pública Soc. Coop. 2003, 47, 41-57.

109. Barba-Sánchez, V.; Calderón, B.; Calderón, M.J.; Sebastián, G. Aproximación al Valor Social de un Colegio Rural Agrupado: El Caso del CRA Sierra de Alcaraz. CIRIEC España Rev. Econ. Pública Soc. Coop. 2021, 101, 85-114. [CrossRef]

110. Greffe, X. The Role of the Social Economy in Local Development. In The Social Economy, Building Inclusive Economies; Noya, A., Clarence, E., Eds.; OECD: Paris, France, 2007; pp. 93-119.

111. Tomás, J.A.; Mozón, J.L. Libro Blanco de la Economía Social en la Comunidad Valenciana; Generalitat Valenciana, CIRIEC: Valencia, Spain, 1998.

112. Chaves, R.; Monzón, J.L. La Economía Social en la Unión Europea; Informe Elaborado por el CIRIEC para el Comité Económico y Social Europeo, CESE, 97; European Economic and Social Committee (EESC): Brussels, Belgium, 2007.

113. Díaz, M.; Marcuello, C. Impacto Económico de las Cooperativas. La Generación de Empleo en las Sociedades Cooperativas y su Relación con el PIB. CIRIEC España Rev. Econ. Pública Soc. Coop. 2010, 67, $23-44$.

114. Calderón, B.; Calderón, M.J. La Calidad del Empleo de las Entidades de la Economía Social en Periodo de Crisis. Ekonomiaz 2012, $79,31-57$.

115. Meliá, E.; Juliá, J.F.; Martinez, A. Mergers of Agrifood Cooperatives and Their Effects from Expectationsto Results. An Empirical Study in four Spanish Autonomous Regions. Span. J. Agric. Res. 2010, 8, 235-250. [CrossRef]

116. Juliá, J.F.; Meliá, E. Social Economy and the Cooperative Movement in Europe: Contributions to a New Vision of Agriculture and Rural Development in the Europe of the 27. CIRIEC España Rev. Econ. Pública Soc. Coop. 2008, 62, 141-168.

117. González, M.R.; García, J.M.G. Economía Social e Igualdad de Oportunidades en el Ámbito Rural. Un Análisis Aplicado a la Comunidad Autónoma de Castilla y León. REVESCO Rev. Estud. Coop. 2011, 105, 85-114. [CrossRef]

118. Santero Sanchez, R.; Castro Núñez, B. Análisis de las Condiciones Laborales en las Entidades de la Economía Social en España desde una Perspectiva de Género. REVESCO Rev. Estud. Coop. 2016, 121, 228-255. [CrossRef]

119. Roelants, B.; Hyungsik, E.; Terrasy, E. Cooperatives and Employment: A Global Report; CICOPA/Desjardin: Levis, QC, Canada, 2014

120. Buendía, I.; Carrasco, I. El Impacto de los Factores Institucionales en la Actividad Emprendedora: Un Análisis del Cooperativismo Europeo. Rev. Econ. Mund. 2014, 38, 175-200.

121. Birchal, J. The Potential of Co-operatives during the Current Recession; Theorizing Comparative Advantage. J. Entrep. Organ. Divers. 2013, 2, 1-22. [CrossRef]

122. Vieta, M. The Emergence of the "Empresas Recuperadas por sus Trabajadores": A Political Economic and Sociological Appraisal of Two Decades of Self-Management in Argentina; Euricse Working Paper No. 55/13; Social Economy Centre, Ontario Institute for Studies in Education, University of Toronto: Toronto, ON, Canada, July 2013.

123. Carrasco, I. La Ética como Eficiencia: La Responsabilidad Social en las Cooperativas de Crédito Españolas. CIRIEC España, Rev. Econ. Pública, Soc. Coop. 2005, 53, 351-367.

124. Carrasco, I. Corporate Social Responsibility, Values, and Cooperation. Int. Adv. Econ. Res. 2007, 13, 454-460. [CrossRef]

125. Carchano, M.; Carrasco, I. La Economía Social y la Industria Agroalimentaria como Factores de Resiliencia de la Población en Castilla-La Mancha. In Despoblamiento y Desarrollo Rural. Propuestas desde la Economía Social; Fajardo, G., Escribano, J., Eds.; IUDESCOOP and CIRIEC-España: Valencia, Spain, 2020. 
126. Vázquez-Barquero, A. Reflexiones Teóricas sobre la Relación Entre Desarrollo Endógeno y Economía Social. Rev. Iberoam. Econ. Solidar. Innovación Socioecológica 2018, 1, 11-22. [CrossRef]

127. Henseler, J.; Ringle, C.M.; Sinkovics, R.R. The Use de Partial Least Squares Path Modeling in International Marketing. Adv. Int. Mark. 2009, 20, 277-320.

128. Hair, J.; Hult, G.; Ringle, C.; Sarstedt, M. A Primer on Partial Least Square Structural Equation Modeling (PLS-SEM); Sage Publications: Thousand Oaks, CA, USA, 2017.

129. Ringle, C.M.; Sarstedt, M.; Mitchell, R.; Gudergan, S.P. Partial Least Squares Structural Equation Modeling in HRM Research. Int. J. Hum. Resour. Manag. 2018, 31, 1-27. [CrossRef]

130. Diamantopoulos, A.; Winklhofer, H.M. Index Construction with Formative Indicators: An Alternative to Scale Development. J. Mark. Res. 2001, 38, 269-277. [CrossRef]

131. Chin, W.W. Issues and Opinion on Structural Equation Modeling. MIS Q. 1998, 22, 7-15.

132. Barclay, D.; Higgins, C.; Thompson, R. The Partial Least Squares (PLS) Approach to Causal Modelling: Personal Computer Adoption and Use as an Illustration. Technol. Stud. 1995, 2, 285-309.

133. Nunnally, J.C.; Bernstein, I.H. Psychonnetric Theory; McGraw-Hill: New York, NY, USA, 1994.

134. Falk, R.F.; Miller, N.B. A Primer for Soft Modeling; University of Akron Press: Akron, OH, USA, 1992.

135. Hayes, A.F. An Introduction to Mediation, Moderation, and Conditional Process Analysis; The Guilford Press: New York, NY, USA, 2013. 